\title{
Ampicillin Resistance and Penicillin-binding Proteins of Haemophilus influenzae
}

\author{
By DEBRA A. SERFASS, 'PAUL M. MENDELMAN,2 \\ DONALD O. CHAFFIN ${ }^{2}$ AND CYNTHIA A. NEEDHAM ${ }^{1 *}$ \\ ${ }^{1}$ Department of Laboratory Medicine, University Hospital at Boston University Medical Center, \\ Boston, Mass., USA \\ 2 Division of Infectious Disease, Children's Orthopedic Hospital and Medical Center, Seattle, \\ Wash., USA
}

(Received 29 April 1986)

\begin{abstract}
Penicillin-binding protein (PBP) alterations have been associated with non- $\beta$-lactamasemediated ampicillin resistance in Haemophilus influenzae. We evaluated the PBP profiles of several ampicillin-susceptible and -resistant clinical isolates of $H$. influenzae to determine how consistently the described alterations occurred, and to document the reproducibility of the PBP profiles for this species. The MIC of ampicillin ranged from 0.06 to $0.13 \mu \mathrm{g} \mathrm{ml}^{-1}$ for the susceptible isolates at an inoculum of $100000 \mathrm{c}$.f.u. when tested by broth dilution, and was $0.5 \mu \mathrm{g} \mathrm{ml}^{-1}$ for all four isolates when tested by agar dilution. The MIC for the resistant isolates ranged from 4 to $8 \mu \mathrm{g} \mathrm{ml}^{-1}$ when tested by broth dilution, and from 1.5 to $16 \mu \mathrm{g} \mathrm{ml}^{-1}$ when tested by agar dilution. At least eight distinct PBPs with molecular masses ranging from 27 to $90 \mathrm{kDa}$ were detected both in cell membrane preparations and whole cell (in vivo) binding assays done on cells in the exponential growth phase. PBP variability was evident both in the ampicillinsusceptible and -resistant isolates; however, much greater variability existed within the four resistant strains. The differences in PBP patterns included (1) electrophoretic mobility, (2) binding capacity for the antibiotic and (3) the presence of additional PBPs in two of the resistant isolates. However, decreased binding capacity was consistently demonstrated in PBP 5 $(56 \mathrm{kDa})$ of all of the resistant isolates. Saturation curves with both penicillin and ampicillin indicated that PBP 5 had decreased affinity for the antibiotics. These results suggest $(a)$ that care should be taken in interpreting changes in PBP profiles for species that demonstrate variability such as $H$. influenzae, and $(b)$ that the decreased binding affinity of PBP 5 is a consistent finding associated with multiple ampicillin-resistant wild-type isolates.
\end{abstract}

\section{INTRODUCTION}

Penicillin-binding proteins (PBPs) are cell-membrane-bound proteins that covalently bind $\beta$ lactam antibiotics; they are present in many Gram-positive and Gram-negative bacteria (Spratt, 1983: Tomasz, 1982). The number of PBPs varies from genus to genus, and their molecular masses range from 25 to $100 \mathrm{kDa}$. These proteins are associated with cell wall synthesis, and are important in such processes as differentiation and cell division. Alterations in an organism's PBP profile may be responsible for increased resistance to $\beta$-lactam antibiotics (Spratt, 1983; Tomasz, 1982). Alterations which have been reported include changes in electrophoretic mobility, in the amount of radiolabelled antibiotic bound, and the absence of a particular PBP. Examples of these changes occurring in conjunction with increased resistance exist for Escherichia coli (Spratt, 1978) and various other organisms.

The association of PBP alterations with non- $\beta$-lactamase-mediated ampicillin resistance in

Abbreviations: PBP, penicillin-binding protein; MBC, minimum bactericidal concentration. 
Haemophilus influenzae has recently been reported. Parr \& Bryan (1984) were able to transform broad spectrum $\beta$-lactam resistance from a resistant clinical isolate of $H$. influenzae into an ampicillin-susceptible recipient strain and show cotransfer of $68 \mathrm{kDa}$ and $65 \mathrm{kDa}$ PBPs with decreased binding for penicillin. Mendelman et al. (1984) subsequently reported the transfer of ampicillin resistance from three of four strains of $H$. influenzae into an ampicillin-sensitive strain. Affinity binding studies on stationary phase cells revealed the presence of a $59 \mathrm{kDa}$ PBP with decreased affinity for ampicillin in all transformants tested.

The purpose of this study was to document the reproducibility of the PBP profile of $H$. influenzae and to examine the frequency with which decreased binding affinity of the two PBPs previously identified occurred in association with ampicillin resistance.

\section{METHODS}

Micro-organisms. Four ampicillin-susceptible isolates of $H$. influenzae, designated H flu S, Hi 261 , Hi 265 and Hi 272, were isolated from respiratory specimens submitted to the Microbiology Laboratory at Boston University Medical Center, Boston, Mass., USA. Three ampicillin-resistant isolates of $H$. influenzae, CDC 76-039256 (CDC 76), CDC 77-046332 (CDC 77) and CDC 78-054472 (CDC 78), were kindly provided by the Centers for Disease Control, Atlanta, Ga., USA; one ampicillin-resistant isolate, recovered from a blood culture and designated $\mathrm{CH}$ Hi l, was obtained from the Children's Hospital, Boston, Mass., USA. Identification of the isolates was confirmed by conventional methods (Killian, 1981); the serotype was determined using slide agglutination with type-specific antisera (Difco). Biotyping was done using the biochemical scheme described by Killian (1980).

$\beta$-Lactamase activity and susceptibility testing. $\beta$-Lactamase production was determined by the chromogenic cephalosporin assay (O'Callaghan, 1972) using both sonicated and whole cell suspensions. In addition, a previously described bioassay system was used to test for biological inactivation of ampicillin (Needham \& Smith, 1980).

Broth dilution susceptibility testing was done in $2.0 \mathrm{ml}$ Fildes (Difco) enriched Mueller-Hinton broth according to the standard broth dilution method described by Thornsberry et al. (1977). The final inoculum tested contained $10^{5}$ c.f.u. The minimum inhibitory concentration (MIC) was defined as the lowest concentration of antibiotic to inhibit visible growth after $24 \mathrm{~h}$ incubation. The minimum bactericidal concentration (MBC) was determined by quantitatively subculturing macroscopically clear tubes. The $\mathrm{MBC}$ was defined as the concentration of antibiotic which reduced the original inoculum by 1000 -fold. Agar dilution assays were done as described by Mendelman $e t$ al. (1984) using an inoculum of $10^{3}$ to $10^{5}$ c.f.u.

Cell membrane preparation. $H$. influenzae isolates were grown in brain heart infusion broth (500 $\mathrm{ml}$ volumes) supplemented with $\mathrm{NAD}^{+}\left(2 \mu \mathrm{g} \mathrm{m}^{-1}\right.$, Sigma $)$ and haemin $\left(10 \mu \mathrm{g} \mathrm{ml}^{-1}\right.$, Sigma $)$ in shaker flasks (200 r.p.m.) at $35^{\circ} \mathrm{C}$. The cells were harvested at the mid to late exponential phase of growth by centrifugation $\left(15000 \mathrm{~g}, 4^{\circ} \mathrm{C}\right.$, $25 \mathrm{~min}$ ). Cell pellets were washed twice with cold $0.01 \mathrm{M}-\mathrm{KH}_{2} \mathrm{PO}_{4}$ buffer, $\mathrm{pH} 7 \cdot 5$, and stored at $-70{ }^{\circ} \mathrm{C}$.

Cell membrane fractions were prepared according to the procedure of Makover et al. (1981) with the following modification : cell pellets were thawed slowly, resuspended in cold $0.01 \mathrm{M}-\mathrm{KH}_{2} \mathrm{PO}_{4}$ buffer, and sonicated on ice 10 to 12 times with 2 min pulses followed by 2 min cooling. Protein concentrations were determined with Coomassie Brilliant Blue G-250 (Eastman Kodak), using bovine serum albumin (Sigma) as the standard (Bradford, 1976). The final cell membrane preparations were stored in $200 \mu \mathrm{l}$ samples at $-70^{\circ} \mathrm{C}$.

Saturation curves. Cell membrane samples were thawed at room temperature and adjusted to a concentration of $5.0 \mathrm{mg}$ protein $\mathrm{ml}^{-1}$ with $0.05 \mathrm{M}-\mathrm{KH}_{2} \mathrm{PO}_{4}$ buffer containing $1 \mathrm{~mm}-\mathrm{MgCl}_{2}, \mathrm{pH} 7 \cdot 5$. Saturation assays were done according to the method of Spratt (1977). Penicillin saturation studies were done by adding $20 \mu \mathrm{l}$ of various concentrations of $\left[{ }^{3} \mathrm{H}\right.$ ]penicillin $\mathrm{G}$ [ethylpiperidinium salt; $25 \mathrm{Ci} \mathrm{mmol}^{-1}\left(925 \mathrm{GBq} \mathrm{mmol}^{-1}\right)$; Merck] to $200 \mu \mathrm{lof}$ the cell membrane fraction. The concentration of penicillin tested ranged from 0.001 to $24 \mu \mathrm{g} \mathrm{ml}^{-1}$. Ampicillin saturation studies were done by incubating $20 \mu \mathrm{l}$ of various concentrations $\left(0.001\right.$ to $\left.24 \mu \mathrm{g} \mathrm{ml}^{-1}\right)$ of ampicillin (Bristol Laboratories) with $200 \mu \mathrm{l}$ of the membrane fraction for $10 \mathrm{~min}$ at $35^{\circ} \mathrm{C}$, and then adding $10 \mu \mathrm{l}$ $\left[{ }^{3} \mathrm{H}\right]$ penicillin (final concentration $3.0 \mu \mathrm{g} \mathrm{ml}^{-1}$ ). The reactions were terminated by the addition of $5 \mu \mathrm{lof} 1.0 \mathrm{M}$ unlabelled benzylpenicillin, and the membrane fractions solubilized in $20 \%$ (w/v) $N$-lauroylsarcosine (Sigma). The reaction mixtures were then prepared for SDS-PAGE as described by Mendelman et al. (1984). Samples containing $27.3 \mu \mathrm{g}$ protein were subjected to SDS-PAGE in a $10 \%(\mathrm{w} / \mathrm{v})$ separating gel with a $6 \%(\mathrm{w} / \mathrm{v})$ stacking gel at a constant current of $30 \mathrm{~mA}$ per gel. Gels were stained, destained and prepared for fluorography according to the method of Bonner \& Laskey (1974). Gels were dried, placed against prefogged Kodak XAR-5 film (Eastman Kodak) and stored at $-70^{\circ} \mathrm{C}$ for $6 \mathrm{~d}$. The fluorograms were developed in a Kodak automated processor and further analysed with a Transidyne scanning densitometer coupled to a computing integrator (Transidyne General Corp.). The $50 \%$ saturation value $\left(S_{50}\right)$ was defined as that concentration of antibiotic required to saturate $50 \%$ of the binding capacity of a particular PBP. As controls for non-specific binding, outer membrane preparations, cell 
membrane preparations pre-incubated with excess unlabelled penicillin, and cell preparations boiled for $3 \mathrm{~min}$ before incubation with $\left[{ }^{3} \mathrm{H}\right]$ penicillin were assayed for PBPs in a similar manner.

$P B P$ profiles. Whole cells were grown to exponential phase in $10 \mathrm{ml}$ supplemented brain heart infusion broth. When the $\mathrm{OD}_{660}$ reached $0 \cdot 60$, a $1 \mathrm{ml}$ sample was removed and the cells were harvested by centrifugation. Cell pellets were washed twice with buffer containing $50 \mathrm{mM}-\mathrm{Tris} / \mathrm{HCl}, \mathrm{pH} 7 \cdot 8$, and $1 \mathrm{mM}-\mathrm{MgCl}_{2}$, and resuspended in $100 \mu \mathrm{l}$ of the same buffer. Ten $\mu \mathrm{l}(0 \cdot 1 \mu \mathrm{g})\left[{ }^{3} \mathrm{H}\right]$ penicillin $[5.42 \mu \mathrm{Ci}(200 \mathrm{kBq})]$ was added to each sample; the samples were then incubated at $37^{\circ} \mathrm{C}$ for $45 \mathrm{~min}$. We previously used a tenfold higher concentration of $\left[{ }^{3} \mathrm{H}\right]$ penicillin $\left(10 \mu \mathrm{g} \mathrm{ml}^{-1}\right)$ which would saturate the binding sites of the PBPs. However, this concentration resulted in high, non-specific background binding which interfered with resolution, interpretive comparisons and densitometry readings. To circumvent the latter problem we used the lower concentration of $1 \mu \mathrm{g} \mathrm{ml}^{-1}$ and did a kinetic study which showed that increasing the binding reaction time from 10 to 45 min gave the maximum detail, allowing PBPs with less affinity to bind. The reactions were terminated as described above and the samples prepared for SDS-PAGE. Samples containing $40 \mu \mathrm{g}$ protein were subjected to electrophoresis $(10 \%, \mathrm{w} / \mathrm{v}$, separating gel $; 4 \%, \mathrm{w} / \mathrm{v}$, stacking gel; constant current of $10 \mathrm{~mA}$ overnight). The gels were fixed, enhanced and dried, then exposed against Kodak XAR-5 film for 9 and $30 \mathrm{~d}$ at $-80^{\circ} \mathrm{C}$ and developed.

Binding of $\left[{ }^{3} \mathrm{H}\right.$ penicillin to whole cells. To assess permeability, whole cell binding was determined by a procedure modified from that described by Hakenbeck et al. (1980). Cells were grown to exponential phase in supplemented brain heart infusion broth and $35 \mathrm{ml}$ samples were removed for analysis. Cells were removed by centrifugation at $12000 \mathrm{~g}$ for $10 \mathrm{~min}$ and resuspended in $3.0 \mathrm{ml}$ sterile $0.01 \mathrm{M}-\mathrm{KH}_{2} \mathrm{PO}_{4}$ buffer, $\mathrm{pH} \mathrm{7.5}$. The suspensions were standardized to an $\mathrm{OD}_{540}$ of 1.0 and viable cell counts were determined. Standardized cell suspensions $(200 \mu \mathrm{l})$ were incubated for $10 \mathrm{~min}$ at $35^{\circ} \mathrm{C}$ after the addition of $20 \mu 1{ }^{3} \mathrm{H}$ ]penicillin [final concentration $3 \cdot 3 \mu \mathrm{g} \mathrm{ml}^{-1}$; specific activity $\left.250 \mu \mathrm{Ci} \mathrm{mmol}^{-1}\left(9 \cdot 25 \mathrm{MBq} \mathrm{mmol}^{-1}\right)\right]$. Excess unlabelled penicillin $\left(5 \cdot 0 \mu \mathrm{l}, 120 \mathrm{mg} \mathrm{ml}^{-1}\right) \mathrm{was}^{-}$ added to each tube and the cells were collected on polycarbonate filters $(0.4 \mu \mathrm{m}$, Nucleopore membrane filters, VWR) that had been pre-soaked in buffered penicillin $\left(250000 \mathrm{U} \mathrm{ml}^{-1}\right)$. Filters were washed twice, dried overnight, and placed in $4 \mathrm{ml}$ Bray's Solution (National Diagnostics) for determination of radioactivity. Five separate determinations were made for each strain and the average c.p.m. were normalized to represent $1.0 \times 10^{9}$ cells.

\section{RESULTS}

\section{Characteristics of the isolates}

No morphological abnormalities were evident when isolates were Gram stained and examined microscopically. None of the isolates were serologically typable. Three biotypes (I, II and III) were represented among the isolates. No $\beta$-lactamase activity and no evidence of biological degradation of ampicillin were detected. When tested by broth dilution, the MIC of ampicillin for the sensitive isolates ranged from 0.06 to $0.13 \mu \mathrm{g} \mathrm{ml}^{-1}$, and the MIC for the resistant isolates ranged from 4.0 to $8.0 \mu \mathrm{g} \mathrm{ml}^{-1}$. The $\mathrm{MBC}$ was similar in all instances to the respective MIC, and no evidence of tolerance was found. When tested by agar dilution using an inoculum of $10^{3}$ c.f.u. $\mathrm{ml}^{-1}$, the MIC of ampicillin and penicillin for all the susceptible isolates was similar: $0.5 \mu \mathrm{g} \mathrm{ml}^{-1}$ and $1 \mu \mathrm{g} \mathrm{ml}^{-1}$, respectively. Similarly, the MIC of ampicillin and penicillin for the resistant strains ranged from 1.5 to $16.0 \mu \mathrm{g} \mathrm{ml}^{-1}$ and from 4 to $16 \mu \mathrm{g} \mathrm{ml}^{-1}$, respectively.

\section{PBP profiles}

Eight distinct PBPs were detected in the four ampicillin-susceptible strains examined in exponential phase (Fig. 1). This observation is in agreement with other investigators (Makover et al., 1981; Mendelman et al., 1984; Mendelman \& Chaffin, 1985; Parr \& Bryan, 1984), and the proteins have been numbered to agree with those described by Makover et al., (1981). Approximate molecular mass assignments for the eight PBPs were as follows: PBP 1, $90 \mathrm{kDa}$; PBP 2, $80 \mathrm{kDa}$; PBP 3, $67 \mathrm{kDa}$; PBP 4, $59 \mathrm{kDa}$; PBP 5, $56 \mathrm{kDa}$; PBP 6, $43 \mathrm{kDa}$; PBP 7, $38 \mathrm{kDa}$; and PBP 8, $27 \mathrm{kDa}$. In contrast, six to ten PBPs were evident in the four resistant strains (Fig. 1). Comparison of the PBP profiles indicates that inter-strain variability exists even among the susceptible isolates. For example, PBPs 2 and 3 in Hi 261 (lane B) have different electrophoretic mobilities from the same PBPs in the other susceptible strains. Reduced binding capacities associated with PBPs 7 and 8 in Hi 272 (lane D) were noted, as well as an apparent increased binding capacity associated with PBP 3 in $\mathrm{H}$ flu S (lane A). However, there was much 


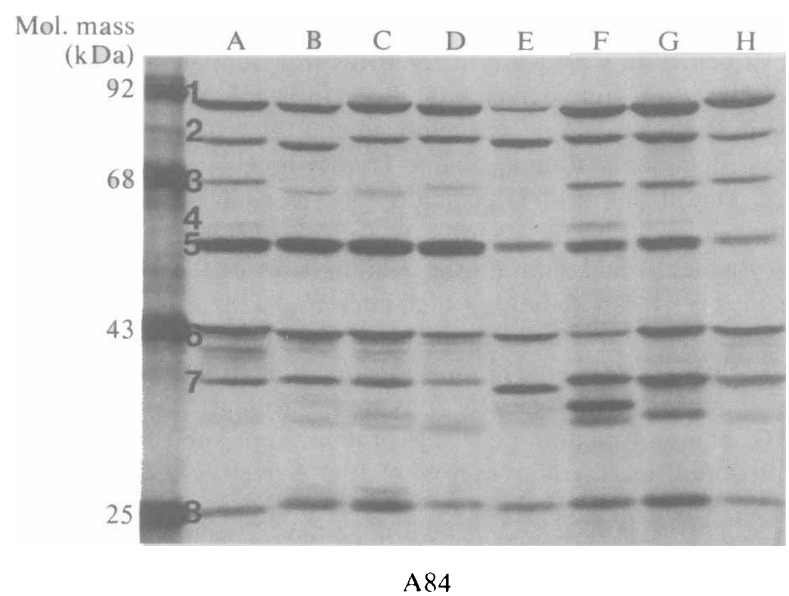

Fig. 1. Detection of the PBPs of ampicillin-susceptible and -resistant, non- $\beta$-lactamase-producing strains of $H$. influenzae. The numbers ( 1 to 8 ) to the left of lane A indicate the major PBPs. Lanes A to D are ampicillin-susceptible strains ( $\mathrm{H}$ flu S, $\mathrm{Hi} 261, \mathrm{Hi} 265$ and $\mathrm{Hi} 272$, respectively); lanes $\mathrm{E}$ to $\mathrm{H}$ are ampicillin-resistant strains (CDC 76, $\mathrm{CDC} 77, \mathrm{CDC} 78$ and $\mathrm{CH} \mathrm{Hi} \mathrm{1,} \mathrm{respectively).} \mathrm{The} \mathrm{lane} \mathrm{to} \mathrm{the} \mathrm{left}$ of lane $\mathrm{A}$ contains ${ }^{14} \mathrm{C}$-labelled standards; their apparent molecular mass is indicated.

greater variability apparent in the four resistant isolates. Electrophoretic mobility differences were observed in PBPs 2 and 7 in CDC 76 (lane E). Reduced binding capacity could be demonstrated for PBP 5 in all four resistant strains (lanes $\mathrm{E}-\mathrm{H}$ ). In addition, the following reductions in binding were noted: PBPs 1,3,4 and 8 in CDC 76, (lane E); PBPs 2, 4 and 8 in $\mathrm{CH} \mathrm{Hi} 1$ (lane H) and PBP 6 in CDC 77 (lane F). Of interest, two of the ampicillin-resistant strains contained additional lower molecular mass PBPs. Strain CDC 77 (lane F) contained two additional PBPs with molecular masses of $35 \mathrm{kDa}$ and $33 \mathrm{kDa}$, respectively. CDC 78 (lane $\mathrm{G}$ ) contained an additional PBP with a molecular mass of $34 \mathrm{kDa}$.

\section{Saturation studies}

Penicillin and ampicillin saturation assays were done on a minimum of three separate cell membrane preparations. Saturation curves were constructed for each of the PBPs when possible. PBPs 4 and 5 did not always separate sufficiently as individual proteins to allow densitometric resolution and consequently they were analysed as a single protein. The penicillin saturation curve for PBP 3 (Fig. $2 a$ ) is representative of the results observed for PBPs 1, 2, 6, 7 and 8 . No consistent finding with these PBPs was associated with the resistant strains that could not be demonstrated in one or more of the susceptible strains. In contrast, a distinct difference was evident between the ampicillin-susceptible and -resistant isolates in the saturation curve of PBPs 4 and 5 (Fig. 2 b). When $S_{50}$ values were calculated for each of the PBPs (Table 1), significantly more antibiotic was necessary to achieve $50 \%$ saturation of PBPs 4 and 5 from the resistant strains. In most cases, the difference was 10 to 100 -fold in magnitude.

\section{Whole cell binding capacity}

The amount of $\left[{ }^{3} \mathrm{H}\right]$ penicillin bound by $10^{9}$ cells of each strain varied from $2059 \pm 347$ c.p.m. to $4604 \pm 694$ c.p.m. The whole cell binding capacity of the strains did not correlate with their susceptibility to ampicillin : three of the four resistant strains bound more penicillin than did the susceptible strains.

\section{DISCUSSION}

The PBP profiles of four ampicillin-susceptible and four ampicillin-resistant isolates of $H$. influenzae were examined in this study using cells grown to exponential phase. The PBP pattern of the ampicillin-susceptible strains was similar to that originally reported by Makover et al. 


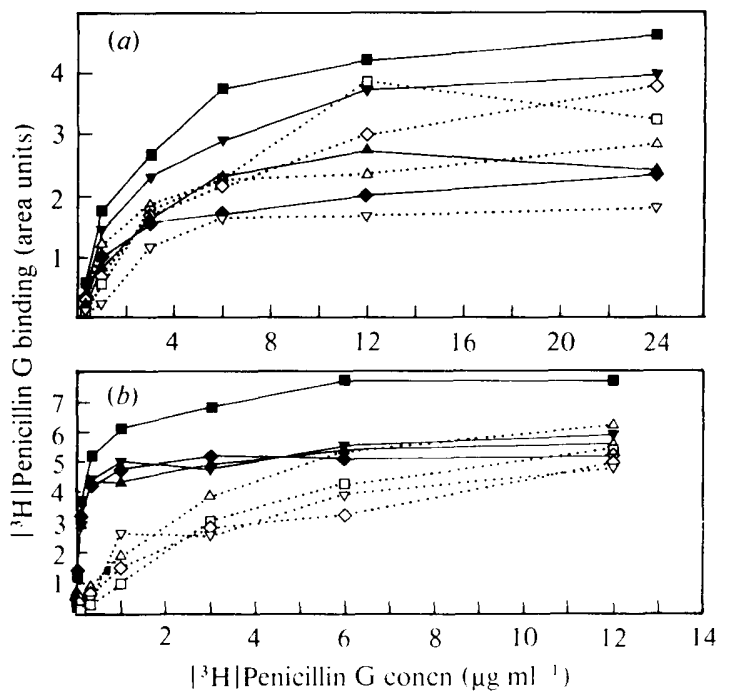

Fig. 2. $\left[{ }^{3} \mathrm{H}\right]$ Penicillin $\mathrm{G}$ saturation curves. (a) PBP $3 ;($ b) PBPs 4 and 5 analysed as a single protein. Each point represents the mean of three separate determinations. The curves were used for the derivation of $S_{50}$ values (concentration of penicillin required to saturate $50 \%$ of the binding capacity of a given PBP). - , Ampicillin-sensitive strains ( $\boldsymbol{\square}$, H flu S; $\boldsymbol{\nabla}$, Hi 261; $\bullet$. Hi 265: $\boldsymbol{\Delta}$, Hi 272): $\cdots$, ampicillinresistant strains $(\square, \operatorname{CDC} 76 ; \nabla, \operatorname{CDC} 77 ; \diamond, \operatorname{CDC} 78 ; \triangle, \mathrm{CH} H \mathrm{Hi} 1)$

Table 1. Fifty percent saturation value $\left(S_{50}\right)$ of $\left[{ }^{3} \mathrm{H}\right]$ penicillin $G$ for PBPs in isolates of $H$. influenzae

$S_{50}\left(\mu \mathrm{g}\right.$ antibiotic $\left.\mathrm{mi}^{-1}\right)$

PBP

(Molecular mass)

H flu S Hi 261 Hi 265 Hi 272 Strain:

l $(90 \mathrm{kDa})$

Pen

Amp

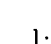

$2(80 \mathrm{kDa})$

Pen

Amp

$3(67 \mathrm{kDa})$

Pen

Amp

$5 \cdot 2$

$1 \cdot 1 \quad 1 \cdot 5$

$5 \cdot 2 \quad 7 \cdot 8$

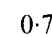

$0.7 \quad 8.2$

$1.9 \quad 2.5$

$2 \cdot 5$

$8 \cdot 2$
$3 \cdot 3$

$1 \cdot 7$

6.8

$0.06 \quad 0 \cdot 2$

$0 \cdot 3$

$0 \cdot 04$

*

$0 \cdot 2$

$1 \cdot 8 \quad 2 \cdot 1$

1.9

0.07

(

CDC $77 \quad \operatorname{CDC} 78$

$\mathrm{CH} \mathrm{Hil}$

4 (59 kDa)

Pen

Amp

0.2

$0 \cdot 7$

$0 \cdot 2$

$1 \cdot 8$

$3 \cdot 2$

$0 \cdot 7$

$\begin{array}{ccc}+ & \dagger & \dagger \\ 0.08 & 0.01 & \dagger\end{array}$

$+$

$3 \cdot 3$

0.5

$7 \cdot 3$

0.9

5 (56 kDa)

Pen +

Amp

6 (43 kDa)

Pen

0.01

$+$

$0 \cdot 1$

$0 \cdot 1$

$0 \cdot 1$

$0 \cdot 1 \quad 3.5$

$3 \cdot 5$

$3 \cdot 5$
$0 \cdot 6$

$2 \cdot 3$

$2 \cdot 7$

Amp

$0 \cdot 1$

$0 \cdot 1$

$0 \cdot 1$

0.03

$3 \cdot 4$

ND

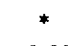

$4 \cdot 1$

(38 kDa)

Pen

0.04

$6.2 \quad 10 \cdot 5$

ND $\quad 7.8$

ND

0.08

0.01

Amp

$8(27 \mathrm{kDa})$

Pen

Amp

4.0

4.0
$<0.001$

$0 \cdot 4$

$0 \cdot 2$

ND

0.03

ND

3.7

$1 \cdot 4$

0.02

$\begin{array}{lr}3.8 & 3 \\ <0.001 & <0\end{array}$

$3.8 \quad 3.5$

2.5
$<0.001$

$4 \cdot 4$
$2 \cdot 7$

$\begin{array}{ll}5.4 & 7 \cdot 2 \\ \text { ND } & 1\end{array}$

$<0.001<0.001$

$<0.001$

$<0.001$

$+$

$3 \cdot 5$

$3 \cdot 5$
$0 \cdot 5$

ND, Not detected by the densitometer.

* PBPs 1 and 2 evaluated as a single protein.

$\uparrow$ PBPs 4 and 5 evaluated as a single protein. 
(1981) for $H$. influenzae ATCC 19148 and to four additional ampicillin-susceptible isolates studied by Mendelman \& Chaffin (1985). Eight PBPs were detected. To date, the PBP profiles of only four ampicillin-resistant isolates have been determined. Parr \& Bryan (1984) reported reduced binding of penicillin with two PBPs in the single isolate tested. Mendelman et al. (1984) examined three strains and showed uniformly reduced binding to penicillin and binding affinity for ampicillin with a single PBP of $59 \mathrm{kDa}$ and, in addition, that other PBPs might be involved. Thus, several PBPs of $H$. influenzae appeared to be associated with the resistant phenotype.

Although some variation in PBP profiles is evident among all eight of the wild-type strains tested in this study, it is striking that much greater variability occurs among resistant than among susceptible strains. However, we were consistently able to demonstrate decreased binding capacity associated with PBP $5(56 \mathrm{kDa})$ in the resistant strains. Further, the decreased binding capacity was related to decreased affinity in all four strains. Our data support the observations of Mendelman et al. (1984) and Parr \& Bryan (1984) for this particular PBP. Of interest is the fact that PBP $4(59 \mathrm{kDa})$ in two of the four resistant isolates appears to have similar binding capacity for penicillin when compared to the four sensitive strains (Fig. 2). This is in contrast to the previous reports and suggests that PBP 4 may be subject to inter-strain variability independent of ampicillin resistance. The PBPs designated 3A and 3B (68 and $65 \mathrm{kDa}$, respectively) by Parr \& Bryan (1984), and PBPs designated 4 and 5 (62 and $59 \mathrm{kDa}$, respectively) by Mendelman \& Chaffin (1985) appear to correspond to our PBPs 4 and 5 (59 and $56 \mathrm{kDa}$, respectively). The differences in reported molecular mass presumably reflect minor differences in technique.

Also of interest is the presence of two PBPs with lower molecular masses not yet described in CDC 77. One of these two PBPs ( $35 \mathrm{kDa}$ ) appears to have a relatively high binding capacity for penicillin. Strain CDC 78 also has an additional PBP of approximately $34 \mathrm{kDa}$. Whether these additional PBPs are simply another example of inter-strain variability or are related to ampicillin resistance must be confirmed by isogenic comparisons. However, it is noteworthy that neither of these two PBPs has been detected in the 10 susceptible strains for which PBP profiles have been examined and reported (Makover et al., 1981; Mendelman \& Chaffin, 1985; Parr \& Bryan, 1984). Since multiple alterations are very likely to involve several genetic steps, transformation studies could identify which PBPs change along with resistance.

This study was supported in part by the following grants from the National Institutes of Health: R23AI2180601, RR07096, RR05655.

\section{REFERENCES}

Bonner, W. M. \& Laskey, R. A. (1974). A film detection method for tritium-labelled proteins and nucleic acids in polyacrylamide gels. European Journal of Biochemistry 46, 83-88.

BRADFORD, M. M. (1976). A rapid and sensitive method for the quantitation of microgram quantities of protein utilizing the principles of protein-dye binding. Analytical Biochemistry 72, 248-254.

Hakenbeck, R., TARPay, M. \& Tomasz, A. (1980) Multiple changes of penicillin-binding proteins in penicillin-resistant clinical isolates of Streptococcus pneumoniae. Antimicrobial Agents and Chemotherapy 17, 364-371

Killan, M. (1980). Haemophilus. In Manual of Clinical Microbiology, 3rd edn, pp. 330-336. Edited by E. H. Lennette, A. Balows, W. J. Hausler, Jr \& J. P. Truant. Washington, DC: American Society for Microbiology.

Killian, M. (1981). Haemophilus. In Medical Microbiology and Infectious Disease, pp. 387-399. Edited by A. I. Braude. Philadelphia: W. B. Saunders.

Makover, S. D., Wright, R. \& Telep, E. (1981).
Penicillin-binding proteins in Haemophilus influenzae. Antimicrobial Agents and Chemotherapy 19, 584588.

Mendelman, P. M. \& Chaffin, D. O. (1985). Two penicillin binding proteins of Haemophilus influenzae are lost after cells enter stationary phase. FEMS Microbiology Letters 30, 399-402.

Mendelman, P. M., Chaffin, D. O., Stull, T. L., Rubens, C. E., Mack, K. D. \& Smith, A. L. (1984). Characterization of non- $\beta$-lactamase-mediated ampicillin resistance in Haemophilus influenzae. Antimicrobial Agents and Chemotherapy 26, 235-244.

Needham, C. \& Smith, P. (1980). Ampicillin resistance in Hemophilus parainfluenzae. American Journal of Clinical Pathology 74, 229-232.

O'Callaghan, C. H., Morris, A., Kirby, S. M. \& Shingler, A. H. (1972). Novel method for detection of beta-lactamases by using a chromogenic cephalosporin substrate. Antimicrobial Agents and Chemotherapy 1, 283-288.

PARR, T. R. \& BRYAN, L. E. (1984). Mechanism of resistance of an ampicillin-resistant, $\beta$-lactamase- 
negative clinical isolate of Haemophilus influenzae type B to $\beta$-lactam antibiotics. Antimicrobial Agents and Chemotherapy 25, 747-753.

SpratT, B. G. (1977). Properties of the penicillinbinding proteins of Escherichia coli K12. European Journal of Biochemistry 72, 341-352.

SPRATT, B. G. (1978). Escherichia coli resistance to betalactam antibiotics through a decrease in the affinity of a target for lethality. Nature, London 74, 713-715.

Spratt, B. G. (1983). Penicillin-binding proteins and the future of $\beta$-lactam antibiotics. Journal of General Microbiology 129, 1247-1260.

Thornsberry, C., Gavan, T. L. \& Gerlach, E. H. (1977). New developments in the antimicrobial agent suspectibility testing. In Cumitech 6, pp. 2-3. Edited by J. C. Sherris. Washington, DC: American Society for Microbiology.

Tomasz, A. (1982). Penicillin-binding proteins in bacteria. Annals of Internal Medicine 96, 502-504. 